\title{
The First Female Performers: Tumblers, Flute-girls, and Mime Actresses
}

\begin{abstract}
Recovering the 'lost' female tradition has been one of the explicit goals of feminist scholarship in theatre history. Live Hov's essay is a contribution to that line of research, focusing on the first female performers in the 'illegitimate' genres of Greek and Roman theatre. By surveying a number of relevant texts, she shows how these important 'firsts' are a neglected area in the theatre and performance studies curriculum. Specialized works by classical scholars provide more evidence on the matter, however, and in the second part of the essay Hov sketches the professional activities and social status of the first female performers. Finally she views the topic through the concept of the gaze, showing how the female performers of antiquity were the first 'objects' of the gaze, which in turn contributed to the persistent notion of the promiscuous actress. Live Hov is Professor of Theatre Studies at the University of Oslo, formerly holding a similar position at the University of Copenhagen. Prior to her academic studies she was trained as an actor at the National Theatre School, Norway. Most of her publications (mainly in Norwegian and Danish) pertain to the history and function of women in theatre, to the history of opera production, and to Henrik Ibsen as a man of the theatre.
\end{abstract}

Key terms: ancient theatre history, antiquity, feminist performance studies, male gaze.

FINDING the 'lost' female tradition has been one of the explicit goals of feminist scholarship within theatre history, as shown by Sue-Ellen Case as well as Elaine Aston in their important works Feminism and Theatre (1988), and An Introduction to Feminism and Theatre (1995), ${ }^{1}$ both of which included a short section discussing the first female performers, as parts of the chapters on 'Women Pioneers' (Case) and 'Finding a Tradition: Feminism and Theatre History' (Ashton).

The aim of the present article is to shed some more light on the women performing in the theatre of antiquity, a group of female practitioners that is not included in Aston's account, though they are described and discussed briefly by Case. Anyway, these performers must be regarded as important 'firsts' in women's theatre, to borrow Aston's own phrase characterizing the tenth-century playwright Hrotsvit. ${ }^{2}$ In her foreword to the 2008 edition of Sue-Ellen Case's Feminism and Theatre, Aston similarly stresses the significance of "recovering the "losts" and the "firsts", the women theatre makers that the canonical had "hidden from history".'3
My general intention is to offer an overview of the professional activities and status of the first female performers. In what arenas and within which contexts did these women perform, what were their particular skills, and what impact did they have on their own time and society? And consequently, what kind of historical significance should be attributed to them, in terms of theatre history in general and more specifically for female performers in later periods? In line with Case and Aston, I will also limit my study to the Western tradition, focusing on the ancient Greek and Roman theatre.

The existence of women performing in the less prestigious theatrical genres of antiquity has been known among scholars since the early days of theatre studies, primarily through the work of Allardyce Nicoll and Margarete Bieber. ${ }^{4}$ Nicoll's Masks, Mimes and Miracles was a pioneering work in the field, with its explicit emphasis on the popular theatre. On the basis of these early works, I will start out by investigating how knowledge about female performers in antiquity has been passed on to our present-day 
academic curriculum within classical and theatre studies. Surveying a number of relevant textbooks, I will look for information on 'the first female performers' in each work, with special attention to the question of when and where they made their entry upon the historical stage.

\section{Hidden from History? ${ }^{5}$}

The performers we are looking for might all be regarded as professional entertainers, belonging to various theatrical or performance genres; they included acrobats, mime artists, dancers, and musicians. All through history women have been actively performing in these fields alongside male entertainers, including periods when women were not allowed access to the 'legitimate' stage, as was the case with the tragic and comic theatre of Greece and Rome, and later the Elizabethan and Jacobean in England.

The female performers of the Roman Imperial age make up a special category, as they appeared in big public arenas and theatres that can hardly be regarded as 'illegitimate' stages. In some scholarly works these performers are referred to just as mimes, regardless of their gender, but more often a distinction is made between 'mime actors' and 'mime actresses'. ${ }^{6}$ The term mime, or mimus, is also used about the genre itself, encompassing the whole era of antiquity, and covering the wide range of performance activities mentioned above. ${ }^{7}$ Furthermore the mime is the common term for one particular genre: the mixed shows of short scripted plays and miscellaneous entertainment, presented in the late Roman period.

Our first stop in this review will concern the comprehensive and more or less extensive textbooks of theatre history, represented by four examples of relatively new or newly edited volumes. ${ }^{8}$

The Oxford Illustrated History of Theatre (1995) has a separate chapter on Greek theatre (by Oliver Taplin), without any specific reference to the gender of the performers. ${ }^{9}$ In the chapter presenting the Roman theatre (by David Wiles) it is stated almost implicitly - that female performers sometimes played the women's parts in mime and pantomime. ${ }^{10}$ Furthermore, there is an illustration, showing a 'pantomime actress [who] holds the three masks with which she will perform'. In another illustration a mime actress can be discerned among several male performers. ${ }^{11}$

In The History of the Theatre (2010) Brockett and Hildy cover the theatre of antiquity in two whole chapters: 'Theatre and Drama in Ancient Greece' and 'Hellenistic, Roman, and Byzantine Theatre'. In both chapters there are separate sections on 'Actors and Acting', but as far as the Greek theatre is concerned, the gender of the actors is not mentioned. When it comes to the Roman theatre, there is one single remark: 'The majority of performers were male, for only in mimes did women appear on stage. ${ }^{\prime 2}$ There is also an illustration, showing a statuette of a 'female mime performer or dancer' ${ }^{13}$

Theatre Histories: an Introduction (2010) similarly includes separate sections on 'Classical Greek Theatre' and 'Drama, Theatre and Performance in the Roman Republic and Empire'. The preface mentions the fact that 'Athenian males performed female as well as male roles' in fifth-century Greek tragedy and comedy, and goes on to state that 'it was only very recently that this aroused significant interest', even though historians knew about the all-male convention. ${ }^{14}$

The recent questioning of this convention is touched upon again - with a reference to Case - in Chapter 2. ${ }^{15}$ In Chapter 3 we find the only remark about female performers in antiquity in a short passage on the mime genre (mimos), stating that this genre featured 'both men and women as performers'. ${ }^{16}$ Compared to the two former books, this volume shows an awareness of the 'gender issue', but when it comes to further information or reflections about the first female performers the three works are equally lacking.

The Cambridge Companion to Theatre History (2013) is made up of a series of thematically - rather than chronologically - based sections, consisting of separate essays written by individual scholars. There is an essay on 'Classical Theatre' by Erika Fischer-Lichte 
that refers briefly to the field where female performers actually appeared, i.e. 'theatrical genres that did not need state support, such as Atellan farce and "mime".'17 Nothing is mentioned concerning the gender of the performers, whether in state-supported theatre or mime, but there is an interesting remark regarding the formerly predominant 'narrow concept of theatre that exclusively comprised performances of written texts', under which 'performances of mimus and similar forms were not subsumed' ${ }^{18}$ As we shall see, such a literary concept still seems to be an implicit - and no doubt unrecognized - premise among some theatre scholars.

The textbooks and monographs to be addressed next are explicitly dedicated to the theatre of antiquity. The History of the Greek and Roman Theater, by Margarete Bieber, first published 1939, is still the standard work of reference for all later works in the field, not least for its wealth of visual sources. ${ }^{19} \mathrm{~A}$ number of the illustrations display female performers in several genres of performance, and the text provides useful information on the multifaceted activities of these pioneers. ${ }^{20}$ Female acrobats, musicians, dancers, and mime actresses from the Greek as well as the Roman tradition are included, whereas most other textbooks, if they touch upon the matter at all, mention only the female performers of the late Roman empire. In this respect Bieber's work is by far the most informative and inclusive of the books discussed in this survey. ${ }^{21}$

The Roman Theatre and its Audience by Richard Beacham (1991) includes a paragraph on 'the performers of mime', stating that the performers, 'who could be men or, significantly, women, were maskless' ${ }^{22}$ There are, however, no further comments explaining why the appearance of female performers was significant, which would have been appropriate in the given context.

David Wiles's monograph on Greek Theatre Performance (2000) includes separate chapters on 'Gender' and on 'The Performer'. Yet there is no information on female performers in the genres we are looking at here, i.e. in the tumbler or dancer/musician categories, though it may have been relevant to mention them in the discussion of Aristophanes' performances, as we shall see. Wiles does include references to women performing in various ritual or traditional situations, such as choral dances, processions, and lamentations. ${ }^{23}$ These 'performers' belong, however, to a different sphere of the performance field and cannot be regarded as 'professionals'.

In The Cambridge Companion to Greek and Roman Theatre (2007) there is a separate essay on 'Lost Theatre and Performance Traditions in Greece and Italy' by Hugh Denard. Despite the title, it turns out, of course, that these traditions are not completely lost after all, even if the sources are scant compared to those pertaining to the 'legitimate' theatre of antiquity. Denard's essay includes much interesting information on the mime and the pantomime, and even though these genres are the most evident arenas for the activities of the female performers, this issue is not discussed or even mentioned. ${ }^{24}$

In one of the other essays in the volume, on 'Masks in Greek and Roman Theatre', Gregory McCart makes one single comment on the matter: 'There is evidence that not all pantomimi were male; women certainly performed at private functions and on occasion in public by the fourth century AD. ${ }^{\prime 25} \mathrm{~A}$ few similar remarks are included in another essay, 'Commodity: Asking the Wrong Questions', by J. Michael Walton: 'Under the emperors women did appear as performers, at least in the mimes. ... They also appeared as combatants in the arena in the time of Domitian.' Theodora, the most famous of all mime actresses, is also briefly mentioned. ${ }^{26}$

\section{Finding the 'Firsts'}

When it comes to books on 'feminism and theatre', 'gender and performance', or more specifically 'the actress', we have already glanced briefly at the seminal works of Case and Aston. We will now take a closer look at these books, supplementing them with a selection of quite recent and clearly relevant volumes.

The two opening chapters of Sue-Ellen Case's Feminism and Theatre deal with 
historical matters, starting with 'a feminist deconstruction' of traditional history. The deconstruction pertains to the dramas of the ancient Greek tragedians and Shakespeare, and to the theoretical writings of Aristotle in the Poetics. Case's starting point is that all of these canonical works reflect a common primary premise, that the main theatrical tradition is built upon 'classic drag: the male creation of female parts' ${ }^{27}$

In this way the absence of female performers within the classical Greek and later Elizabethan theatre is clearly brought to the fore, more so than in any of the other books surveyed in this section of my article. The female performers who did work in other genres are not, however, given as much emphasis by Case as the 'Women Pioneers' discussed in her second chapter - not performers but female playwrights. Besides the already mentioned Hrostwit, they are Aphra Behn and Susannah Centlivre, Sor Juana Inez de la Cruz, and Mercy Otis Warren, all of them being 'first' in their particular context.

The 'women mimes' of Greece and Rome are mentioned in this chapter as well, but strangely they are presented as 'the first women playwrights'; they are not seen as pioneers in their own right. ${ }^{28}$ The creation of 'text' is seen as their essential significance; they 'created in the medium their culture allowed them - the language of the body'. The idea that they were makers of plays is stressed again and again: 'Their theatre tradition was a silent one, consisting of physical dramatic invention. Their bodies were the sites of their texts'; they were 'silent women playwrights'.

Fascinating as this notion may be as a tribute to women's dramatic creativity at a time in history when there were no female playwrights in the 'legitimate theatre', it gives a somewhat misleading impression of what the mime actresses actually did. As we shall see in the next section of the article, many of them were certainly not 'silent'; some played instruments, others performed actual play texts in the scripted mime. 'Within a feminist context, these women mimes might be identified as playwrights', Case states once again, and one wonders why it is of such impor- tance to identify them as playwrights rather than performers or actresses. In my view, the women mimes recognized as performing artists should be regarded as equally significant within a feminist context. ${ }^{29}$

Apart from these objections on my part, the pages on the mime actresses include more 'facts' about them than most of the other books surveyed here. We learn that some of them performed in the market places and the streets of Greece and Rome, that they were - and often still are - referred to as 'actress-courtesans', and that the story of the mime actress Theodora is remarkable in many respects. For some reason there are no references to Bieber, ${ }^{30}$ the standard work in the field, and the overall impression is somewhat vague and imprecise.

\section{Prioritizing Playwriting}

As already stated, Elaine Aston does not mention the first female performers of Greece and Rome in her Introduction to Feminism and Theatre, even if she stresses the importance of finding 'the lost tradition' and the 'firsts'. But here again, as in Case's work, it appears - more or less implicitly - that the tradition that feminist scholars have been searching for pertains more or less solely to playwriting in the first place. ${ }^{31}$ Nonetheless, Aston obviously supports Susan Bassnett's critical remarks about the emphasis of so much theatre scholarship on text-based theatre', which 'creates an imbalance'. She also quotes Bassnett's reference to the history of pre-Renaissance performance, when the actor, performing a scenario or play, was one of a much wider group of dancers, singers, musicians, jugglers, and artistes of all kinds' ${ }^{\prime 32}$ We know that this group included female performers as well as male, but neither Bassnett nor Aston brings up the gender of the performers.

The emphasis on the dramatic text has hindered investigations into theatrical texts and contexts, according to Aston, who goes on to state that feminist theatre history has begun to move in the direction of studying 'the following key areas: actresses and their working conditions; women as theatrical 
managers and directors; and the female performer as text'. ${ }^{33}$ The remaining part of Chapter 2 deals with these issues, but only within a post-Renaissance context, or rather, from the Restoration onwards, which means that it is treated from a British point of view. Strangely, there are no references to the earliest modern era actresses of Italy and Spain (and a little later France), who were active and visible on the European continent for about a hundred years before the first English actresses appeared on the stage in 1660 .

In the anthology Die Schauspielerin (2000) quite a few of the articles deal with German theatre history, but there are also texts about the women in the early commedia dell'arte companies, and about famous individual actresses of the nineteenth and twentieth centuries. Many of the articles are 'thematic', in the sense that a certain phenomenon is discussed across national borders. Female pre-Renaissance performers are not treated at length, but the Introduction includes about one page on the mime and pantomime actresses of Imperial Rome. Several of the important points of their story are mentioned briefly, such as the concept of the actress/prostitute and the almost obligatory story of the mima Theodora, who became the Empress of the Eastern Empire. ${ }^{34}$

The Routledge Reader in Gender and Performance (1998) consists of a sequence of excerpts from more extensive articles, edited in thematic sections. The chapter on 'Finding a Tradition: Feminism and Theatre History' is taken from Elaine Aston's An Introduction to Feminism and Theatre, the contents of which I have already been commented on. One of the first chapters, by Jane de Gay, provides an 'overview of women in theatre' from 1500 to 1900', in which, therefore, the female performers of antiquity are not included. ${ }^{35}$

The chapter starts with a short survey of 'Women Actors', correctly naming the Italian Isabella Andreini (1562-1604) as 'one of the earliest prominent female actors in Europe' ${ }^{36}$ Against this background the next sentence, stating that 'professional actresses began to emerge in the late seventeenth century' seems rather confusing. As already pointed out, this was the case in England, whereas the Italian and Spanish territories had professional actresses a hundred years earlier. Again, there seems to be a tendency to see theatre history mainly from a British perspective. ${ }^{37}$

The Cambridge Companion to the Actress (2007) displays a similar bias, treating the occurrence of early female performers only in relation to the British tradition in the modern era. According to the blurb on the back of the book it 'is a unique collection of essays on the cultural role of performing women on stage and on screen, throughout history and across continents - from Nell Gwyn to . . . Halle Berry'. Admittedly, the Introduction states that "the first "actresses" in anything like the modern sense of the word, were Italian', which is a reasonable way to delimit the concept. The time perspectives that follow are, however, rather misleading: 'According to the most recent scholarship, they were, at least until the fifteenth century, mainly courtesans. ${ }^{38}$

To my knowledge there is no evidence of 'actresses in the modern sense of the word' in fifteenth-century Italy; the very first sources date from the second half of the sixteenth century, closely connected to the emergence of the commedia dell'arte. ${ }^{39}$ Earlier there were certainly female performers of various sorts in Italy as everywhere else - singers, dancers, jugglers, etc. - but the point is that these are not normally called 'actresses', at least not in the modern sense of the concept. Gilli BushBailey states, however, in her article on 'Revolution, Legislation, and Autonomy', that Italy, Spain, and France admitted actresses to the stage from the mid-sixteenth century, ${ }^{40}$ which is more in accordance with the historical evidence than the statement made in the Introduction. The female performers of antiquity, including the mime actresses, are not mentioned at all in this volume, not even as predecessors of the modern era actresses.

\section{The Neglect of Female Performers}

Summing up this overview, it seems to be quite evident that the existence of the first female performers of antiquity still remains a 
neglected topic in textbooks and anthologies on theatre history and on Greek and Roman theatre, whether through lack of interest or lack of knowledge. Even in specialized studies on women and performance these important 'firsts' are often overlooked, probably due to the still partly prevailing 'literary premise' mentioned above. As we have seen, several of these texts link the appearance of 'the first actresses' to the performance of regular drama texts on the post-Renaissance stage, and furthermore confine the context to the British tradition.

But even if one stuck to a concept of 'the actress' as being in a more specific category than 'the female performer', the Roman mime actresses could have been included as obvious first representatives of the tradition. On the other hand, most modern scholars seem to agree that there is no clear borderline between 'theatre' and all kinds of 'performance', conceived as 'the display of skills'. ${ }^{41}$ Applying such a wider definition, all female entertainers - the tumblers, musicians, and dancers - will easily fit as important 'firsts' in theatre history in general, and not only within a feminist context. The fact that all these performers are commonly neglected might be an indication of a deep-rooted and still prevailing attitude: as men were the actual and self-evident protagonists of the Greek and Roman theatre, it is a matter of less importance whether women performed or not in non-prestigious genres.

Of course, one cannot expect lengthy and detailed descriptions of a multitude of interesting topics in basic textbooks. More substantial material is to be found in specialized studies by classical scholars of art, literature and archaeology. I will be relying on their work when I sketch out some traits of the activities and the social status of the first female performers.

\section{Performing for Socrates at the Symposium}

The extant sources concerning the mimes are relatively scarce, since this was a low status activity and partly improvised. Nevertheless, written as well as pictorial sources from the classical Greek period onward provide us with significant information about the performers. The most striking piece of literary evidence pertaining to the female entertainers in particular is the tale told by Xenophon (430-354 BC) in his Symposium, which is part of his collection of Socratic Dialogues. ${ }^{42}$ It is commonly agreed that the text was written in the late 360 s, whereas the 'dramatic date' - i.e. the time of the event itself - is known to be 422 .

In this dinner party, which took place at a private house in Piraeus, Socrates was present with a group of male friends, and according to the customs of the time, the guests were served with various entertainments along with the food and wine. On this occasion a Syrian impresario provided a kind of cabaret, featuring 'a girl who was an expert flautist, another who was an acrobatic dancer, and a very attractive boy who both played the lyre and danced extremely well' ${ }^{43}$ (See Fig. 1.) In between the different segments of the performance the guests were engaged in conversation, commenting on the performers and their skills, as well as drawing parallels with philosophical questions.

Apart from the pure musical numbers, there was a series of acrobatic presentations, beginning with the acrobat girl dancing with hoops, while the other girl played the flute. 'A man standing by the dancer handed her out hoops to the number of twelve. She took them and threw them spinning up into the air as she danced, judging how high to throw them so as to catch them in time with the music.' The next number was a sword dance: 'a circular frame was brought in, closely set all round with upright sword blades; and the dancer turned somersaults into this and out again over the blades, so that the spectators were afraid that she would hurt herself; but she went through her performance confidently and safely. ${ }^{\prime 4}$ We also learn that the dancer, in another part of her performance, 'had formed the shape of a hoop by bending over backwards'. ${ }^{45}$

Later in the evening, 'they began to bring in a revolving platform for the [female] dancer, who was going to show off a novelty dance on it', but Socrates, in a long argument, suggested that he would now prefer to 


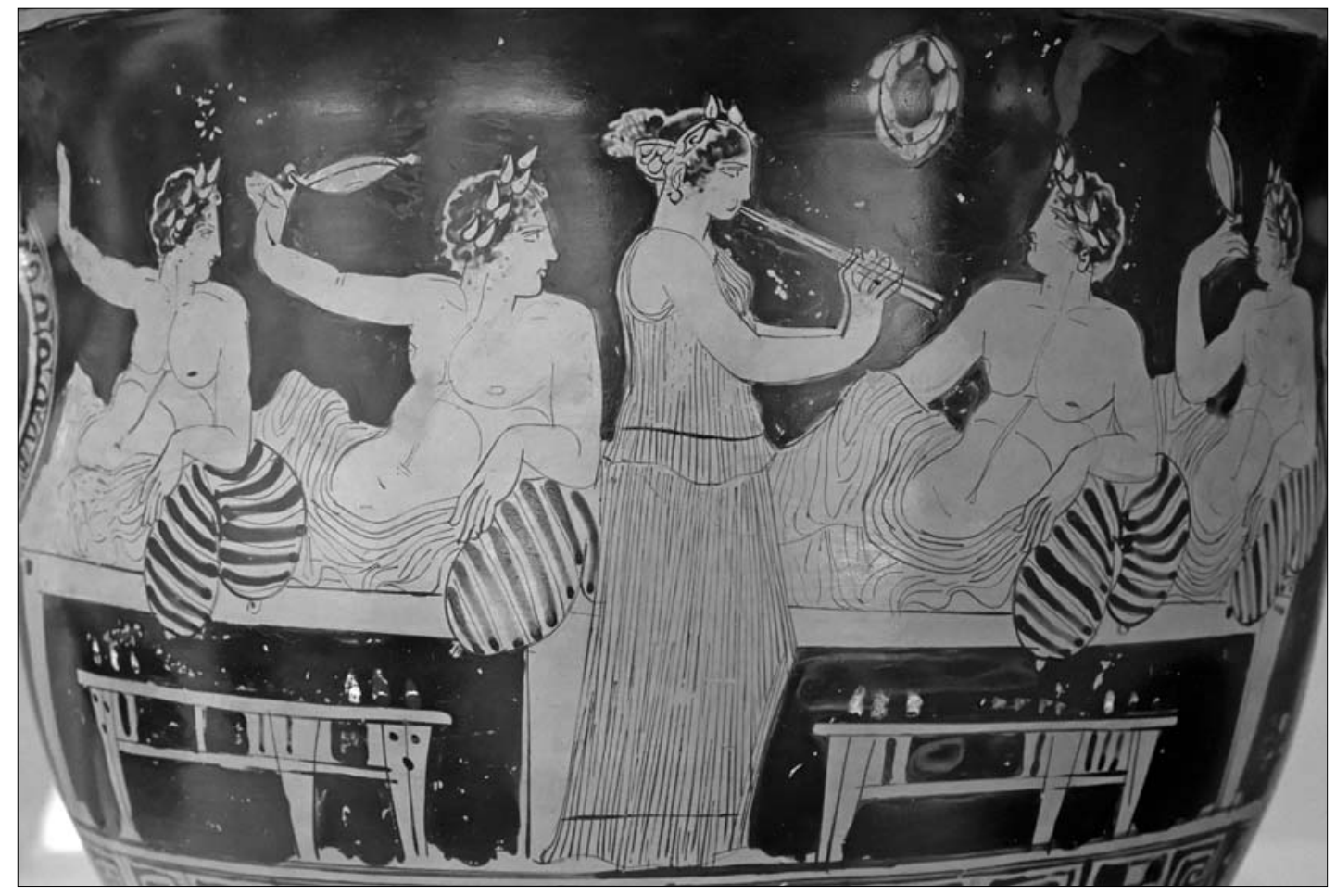

Fig. 1. Male guests at a symposium, leaning on pillows and playing a certain Kottabos game, flinging their wine cups, entertained by a hired flute-girl. Attic red-figure bell-crater painted by Nikias, c. 420 BC. Salamanca Collection.

see the young people dance 'figures representing Graces and Seasons and Nymphs'. ${ }^{4}$ After a while his request was acted out, in a dance or rather pantomime scene, including some spoken lines, showing the love of Ariadne and Dionysus.

The performance is described at length in the final chapter of the Symposium. ${ }^{47}$ It appears that the scene was partly improvised, that the boy and the girl acted very realistically - at least the audience perceived it as being true to life, watching the figures dance, and 'as they kissed and embraced each other'. The guests 'were all carried away with excitement as they watched', and by the end of the performance, viewing the two lovers in each other's arms, 'as if they were going off to bed, the bachelors swore that they would get married, and the married men got into their carriages and drove away to their own wives, with the same end in view' ${ }^{4}{ }^{4}$

Several parallels to the acrobatic and dancing activities described in the Symposium can be seen as motifs on a number of
Greek vase paintings, which are probably the earliest depictions of female performers. On an Attic vase from the first part of the fourth century BC a girl is portrayed as dancing between swords planted in the ground, accompanied by a female flute player, while a girl on a table evidently intends to drink from a saucer in front of her, her back bent backwards into a hoop. ${ }^{49}$ Bieber also shows a vase with a girl holding a similar hoop position, but also shooting an arrow with her feet, which are raised high above her head. On two other vases girls are pictured as performing different versions of the sword dance. ${ }^{50}$

The performance on the revolving platform, also mentioned by Xenophon, corresponds to the scene shown on a vase from Paestum, where a female acrobat performs her handstand act atop such a device, which is probably a potter's wheel. ${ }^{51}$ The girl on another vase executes a similar act, balancing on a low table. It is worth noticing that most of the performing girls are depicted as being more or less naked, whereas the men 
watching - on the two vases just mentioned are fully dressed. (See Figs. 2 and 3.)

The men are also masked, contrary to the girls, which means that these pictures bring us closer to a strictly theatrical context than those on the other vases. The grotesque masks and the short tunics are typical of the 'Old Comedy' of Athens, mainly known from the works of Aristophanes, but were also used in another comic genre, the socalled phlyax farce of the Greek colonies in Southern Italy. According to the provenance of the two vases, they show scenes from that genre, which - like the comedy and tragedy of Athens - is commonly known to have used only male actors. This being the case, what then are female performers doing in that context?

According to the classical scholar C.W. Dearden, there is good reason to assume that the theatrical conventions were less strict in the Greek colonies than in Athens. He thus suggests that the acrobats we see on the vases are actual women participating in the performance, 'rather than the male imitation of the real thing, ${ }^{52}$ This brings us to a parallel issue concerning flute-girls, dancing girls, and female characters in general in the small, non-speaking roles of the comedies of Aristophanes. Such roles occur in Acharnians (1091, 1093, 1198), Knights (1389 ff.), Wasps (1326 ff.), Peace (728, 855, 866), Lysistrata (114 ff.), and Thesmophoriazousae (1172 ff.).

In most of these cases, the women appear naked according to the play text, but it is hard to know how this was actually done in performance. Some scholars have argued that real women performed, as an exception to the main all-male convention, and that the nakedness was genuine as well. Others have pointed out that whether men or women performed, the nakedness might have been faked, by the use of skin-coloured body stockings with the appropriate sexual markings. Those who support the first opinion, like Walton and McLeish, argue that performers for such minor characters could easily be provided from the mixed group of female musicians, dancers, and acrobats that were bought or hired for various purposes of entertainment. ${ }^{53}$ The flute and harp girls also appear as speaking as well as mute characters played by male actors, in the Greek and Graeco-Roman genre of New Comedy. ${ }^{54}$ Among the most prominent are the harp girls Habrotonon in the Epitrepontes fragments by Menander, and Acropolistis in Plautus' Epidicus. ${ }^{55}$

The female performers belonged to the social class of the hetaerae, or courtesans, which formed part of the large and varied population of slaves. From several sources we know that there were schools for flutegirls in Athens. Again, Socrates is involved: the Greek satirist Lucian mentions Socrates 'the wisest of men' - who frequently visited the schools of the flute-girls. Whether this reference is historically correct or not, it supports the notion that these girls were professional, trained musicians. As such they could participate at private parties and celebrations like the Symposium, where respectable citizen women were not allowed. The full or partial nakedness of the performing 'girls' corresponds to that of the other courtesans present, as seen on numerous vase paintings, and was no doubt an extra attraction for the male audience.

\section{The Roman Mimae: Myths and Facts}

In our survey of textbooks we saw that the female performers and mime actresses of the Roman era are somewhat more visible in the historical accounts than their earlier Greek counterparts. Generally the texts treat the subject superficially, however, by stating a few 'facts' without the proper references. Nicoll and Bieber do include many historical and philological details, and both present a rich selection of valuable illustrations, but these older works need to be supplemented by some more recent scholarship. Luckily several classical scholars have made contributions to the field, especially in the recently published studies by Evelyn Fertl and Ruth Webb. Fertl's work (2005) on the actresses of Roman antiquity is written in German, however, ${ }^{56}$ and so is less accessible for the international community than Webb's Demons and Dancers: Performance in Late Antiquity (2008). ${ }^{57}$ On the basis of the research of these 

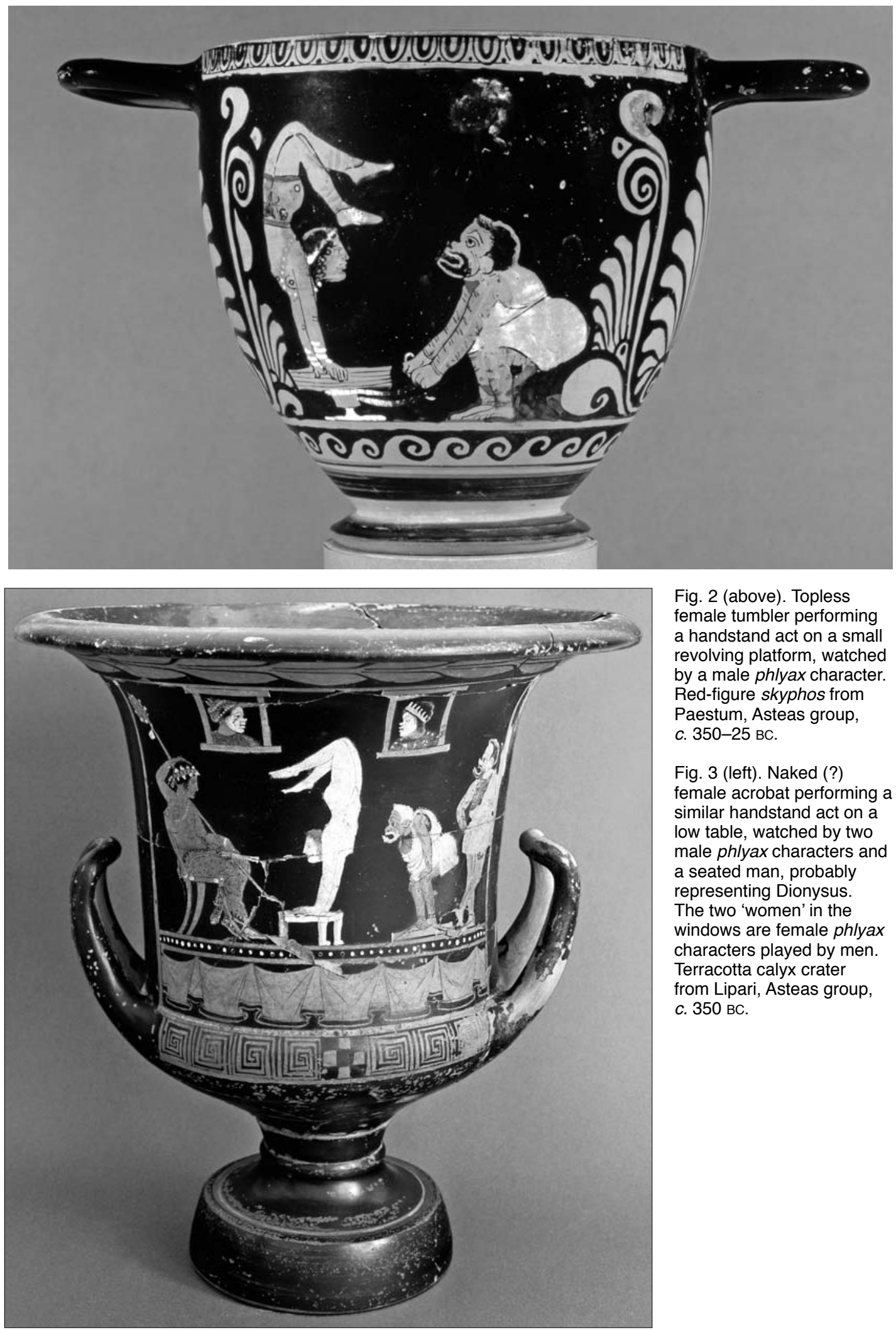

Fig. 2 (above). Topless female tumbler performing a handstand act on a small revolving platform, watched by a male phlyax character. Red-figure skyphos from Paestum, Asteas group, c. $350-25 \mathrm{BC}$.

Fig. 3 (left). Naked (?) female acrobat performing a similar handstand act on a low table, watched by two male phlyax characters and a seated man, probably representing Dionysus. The two 'women' in the windows are female phlyax characters played by men. Terracotta calyx crater from Lipari, Asteas group, c. $350 \mathrm{BC}$. 
two and other scholars, I will sketch some significant traits pertaining to the professional and personal life of the Roman female performers.

As in the classical Greek tradition, there were no clear boundaries between dancers and other entertainers in late antiquity, i.e. the last centuries of the Roman republic and the era of the Roman Empire. Webb consequently treats the female performers as one group, with minor variations, whether they were called mima, saltatrix, embolaria, scaenica, or thymelica. ${ }^{58}$ The nationality of the performers was varied as well: they came from all parts of the Graeco-Roman world, and many of them were constantly travelling within this vast territory. ${ }^{59}$

Such was, evidently, the background for the farewell-poem, written by Antipater in Sidon sometime during the second century $\mathrm{BC}$, to the actress, sometimes called singer or dancer, Antiodemis, on her departure for Rome. In the poem she is described as 'the nursling of Aphrodite' and 'the delightful toy of Methe (Intoxication)'. Furthermore, the poet asserts that the glance of her 'melting eyes is softer than sleep', and that her 'arms flow like water'. In the concluding line a hint is made regarding the purpose of her trip: 'that by her softening charm she may make Rome cease from war and lay down the sword'. ${ }^{60}$ The text confirms the general erotic appeal of the female performers, as numerous later sources also testify. It is rather unusual, however, for this to be linked to a potential peace process.

Another itinerant actress was a certain Verecunda, who is in fact 'the first performer in Britain known by name', according to Simon Trussler in The Cambridge Illustrated History of British Theatre (1994). Described as a 'ludia', or female player, 'her name is scratched alongside that of Lucius the gladiator' on 'a shard of Italian redware pottery found at Leicester, dated somewhere between the first and the fourth centuries $\mathrm{AD}^{\prime}{ }^{61}$ Itinerant performers such as Verecunda and Lucius probably appeared in the Roman theatre buildings that existed in all parts of the empire, as well as in various kinds of smaller venues. ${ }^{62}$
The female entertainers made up quite a numerous group of professionals; according to the historian Ammianus Marcellinus there were 3000 saltatrices present in Rome during the famine of $383 \mathrm{AD} .{ }^{63}$ We know that there were guilds of mime actresses, Sociae Mimae, in Rome, ${ }^{64}$ and from an interesting contract between the crotalistria (castanet dancer) Isidora and a woman named Artemisia, we are provided with a glimpse into the practical concerns of the business such as costumes, transport, and security. ${ }^{65}$ Apart from Rome, the capital of the Eastern Roman empire, Constantinople, was a major centre for mime performances.

Out of the thousands of mime actresses that were performing in the Roman territory through the centuries, about 55 individual names are known. ${ }^{66}$ Some of them are mentioned in several sources, which gives us a hint of their official standing. Arbuscula was known to be bold and lofty-minded, Dionysia was very rich, whereas Volumnia Cytheris was known also as a courtesan, being the mistress of Mark Antony and (later, probably) of Brutus.

Claudia Hermione and Fabia Arete are both referred to as archimimae, signifying that each of them was the leader of the troupe she belonged to. ${ }^{67}$ As such they were, we must assume, confident and competent professionals in their field. Bassilla and Eucharis, who are known mainly because of epitaphs dedicated to them, were also remembered for qualities other than their sex appeal: Eucharis is described as learned and erudite, and in Bassilla's case the epitaph notes the fame she won for her multifarious talents. ${ }^{68}$

A couple of 'fictional or fictionalized' mime actresses from the latter part of antiquity also stand out from the anonymous mass of female entertainers, having 'the fullest biographies and by far the best stories'. ${ }^{69}$ Pelagia proclaimed her conversion to the Christian faith in the midst of a performance of a so-called Christological mime, which was a genre mocking the Christian minority and their religion. The incident is supposed to have happened around 450 AD. From then on she changed her sexual identity by dressing in men's 


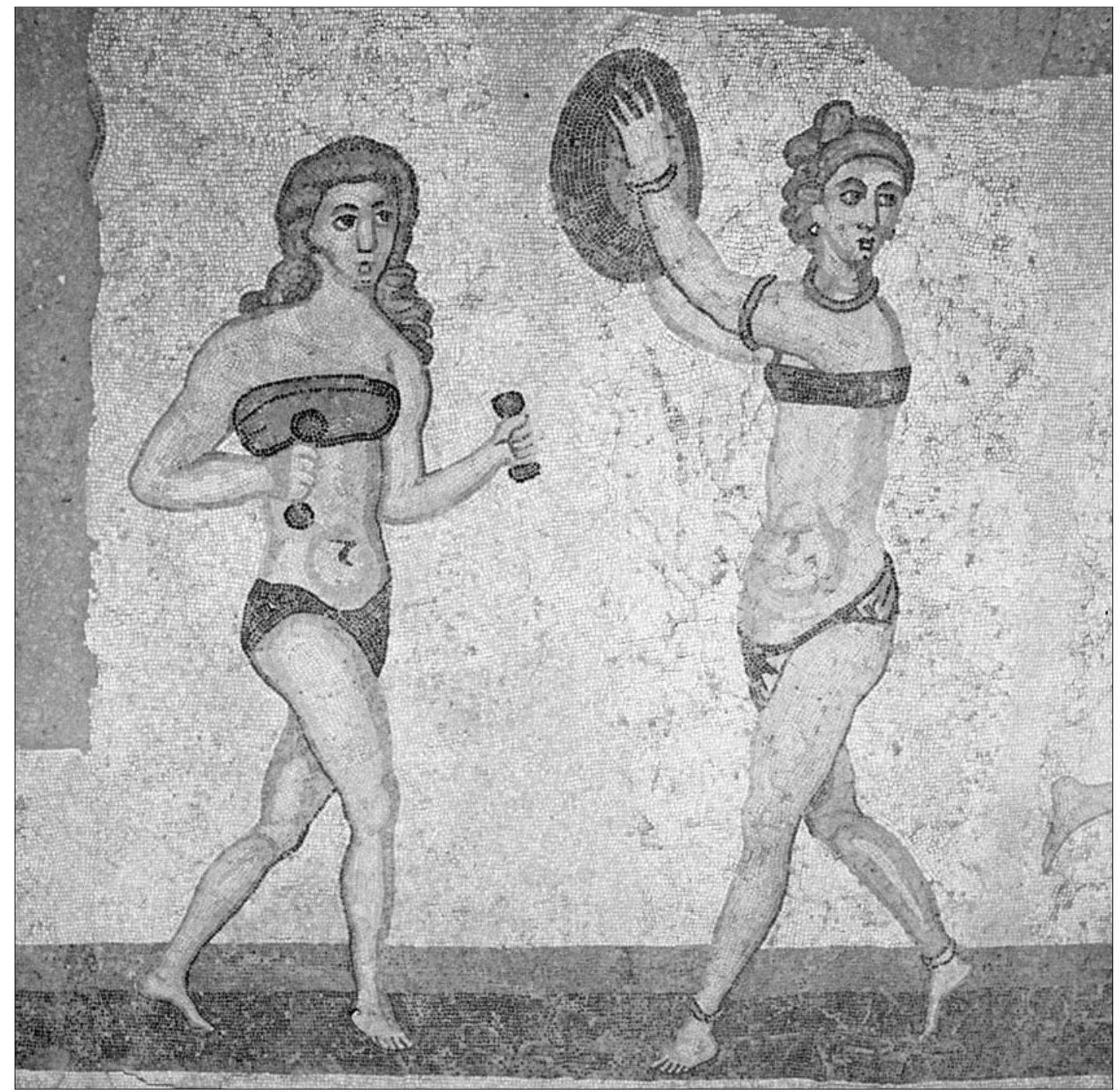

Fig. 4. Roman female entertainers, dressed in 'bikinis', performing with clappers and tambourine, probably in a water ballet. Detail from a larger mosaic at the Villa Romana del Casale, Sicily, c. 300 AD.

clothing and changing her name to Pelagius. When she became canonized post mortem, her identity was reversed again, and in posterity she is known as the female Saint Pelagia. ${ }^{70}$

The story of the aforementioned mima Theodora is just as spectacular, though in another sense, as she ended up being the wife of the Byzantine emperor Justinian (in the sixth century $\mathrm{AD}$ ). She seems to be the oldest example of the actress who attracts the attention and desire of a prominent man and then marries him, thus placing herself way above her original social class. ${ }^{71}$ Records of these women, which can be found in all later epochs, show that they generally chose to or had to - leave the stage as soon as they were married, as was also the case with Theodora.

In the pictorial evidence showing mime actresses of the Roman tradition there is hardly an example of obvious nudity that can be said to be on a par with the Greek examples, except for the well-known mosaic with the 'bikini dancers'. ${ }^{72}$ (See Fig. 4.) Nevertheless the supposed general nudity of the female performers has been a major issue in descriptions of the Roman mime actresses, 
starting in their own era and lasting (almost) until today. Nicoll questioned this assumption, but even so one of his remarks seems to reveal the traditional attitude towards female performers: 'The young actresses, like most actresses of all time, were, it would seem, dressed either too lavishly or not at all. ${ }^{73}$

It is a fact, however, that the mimae had a penchant for wearing rich and expensive robes, both on and off stage, and there were even certain laws forbidding actresses from wearing gems, silk woven with figures, or fabric with gold or purple threads. ${ }^{74}$ Despite his remark, Nicoll's conclusion - after having examined the ancient sources - was similar to the one Webb arrived at some seventy years later: that certain phrases in the writings of Valerius Maximus, Prokopios, and not least John Chrysostom have been misinterpreted or taken too literally, and as a whole, the sources are too scarce and too obscure for absolute conclusions. 'So all that can be said with any confidence is that mime actresses revealed more of their bodies than John Chrysostom, a Christian with ascetic leanings, considered to be appropriate for a woman. ${ }^{75}$

Similarly, the common cliché about mime actresses taking part in real intercourse on stage seems to stem from misinterpretations; if explicit sex scenes were included in the mimes, the action was most likely based on imitation. ${ }^{76}$

The most established and best-known supposition about Roman mime actresses is that they were prostitutes. This notion goes back to their own time, as pointed out by Webb: 'The association of the stage with prostitution is ubiquitous in late antique sources: in late Greek, porne ("harlot" or "prostitute") becomes a regular term for a female stage performer.' 77 Describing the actresses as pornai, as seen in the writings of John Chrysostom and others, did not necessarily imply an accusation of actual prostitution, but rather that illicit sexual conduct was involved in their activities on stage. Nevertheless there was a close connection between the worlds of entertainment and prostitution, and the actresses were commonly considered to be easily available for sexual employment. This was no doubt true for some of them, but certainly not for all, and the notion of the general immorality of actors and dancers was open to debate by contemporary writers.

Whereas actors in the classical Greek theatre were respected citizens who enjoyed a high social status, the Roman actors, in the time of the republic as well as in the imperial age, were slaves or freedmen. In other words they belonged to the lowest social strata, regardless of their occupation, and as actors and entertainers they were shown even greater disrespect. The theatre in general was regarded as immoral and low, even if it was extremely popular, and this double standard was extended to performers of both sexes. All fell under the suspicion of prostitution, and a range of restrictions on their civic rights were imposed, on a par with pimps, (real) prostitutes, wild beast fighters, and criminals.

Even if all performers were victims of this social and legal stigma, which is known as the Roman infamia, the female entertainers were regarded as lower and more despicable than the men. ${ }^{78}$ The main reason for this must have been the deep-rooted notion that respectable women should not perform and certainly not speak in public. In the mime the actresses and dancers even appeared without masks - which were traditionally used by male actors in the other theatrical genres and they were probably scantily dressed on some occasions. The often erotic content of the performances, among them the so-called adultery mime, evidently enhanced the sinful and lewd image of the actresses.

\section{The Question of the 'Gaze'}

With a very few exceptions, all the writers of antiquity were male. Accordingly, the image of the mimae, as it is handed down in history, was shaped by the way these men regarded them, for better or worse. In Feminism and Theatre Sue-Ellen Case suggests that the male desire projected upon the female performer created the image of the woman as 'courtesan'. ${ }^{79}$ She does not, however, connect this idea explicitly to the concept of the male 


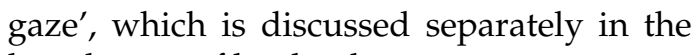
last chapter of her book.

As is now well known, this concept was based on the psychoanalytical theories of Freud and Lacan and first introduced to feminist film theory by Laura Mulvey in 1975, where it was linked to the notion of 'scopophila', the pleasure of looking. According to Mulvey, women generally became passive objects of the male gaze, performed by men as active subjects. ${ }^{80}$

Case discussed how the central ideas concerning 'the male gaze' could be extended to the theatre: 'In the realm of audience reception, the gaze is encoded with culturally determined components of male sexual desire, perceiving "woman" as a sexual object.' By means of the dramatic text, the staging and the production as a whole, the conceptual and visual frames for the audience's looking are established, as seen by men. In the next instance, when the play is performed, the male gaze will be activated, going from the auditorium in the direction of the stage. And even though there are women spectators present among the men, the gaze will inevitably be predominantly 'male', because men initiate and control the production process. ${ }^{81}$

Even if Case does not include any specific historical references in the discussion, she seems to relate these theories mainly to the modern theatre. In my opinion the relevance of the 'male gaze' theory might be considered as universal for all theatre and performance, regardless of genre, venue, and historical time, as long as 'real women' participate in the actions presented for the audience. Naturally, the effect is enhanced when the dramatic content is conceived as erotic or romantic. From this perspective the flute-girls and the mimae of antiquity were 'the firsts' in the genealogy of female performers to become objects of the gaze.

As pointed out by Ruth Webb, the Christian tirades against female performers of Church fathers like John Chrysostom reveal a quite different view on subjectobject dynamics. 'Far from being the active source of a controlling gaze, the male spectator of the woman on stage, at a feast or even in the street, is presented in our texts as a passive victim. ${ }^{82}$ According to this way of thinking, 'women, their bodies and their visibility need to be controlled because of the active sexual power they exert over men'.83 In other words, the relationship between the active male subject and the passive female object, which is the basic premise of modern gaze theories, is reversed if compared to the assumptions of the early Christian writers. Nevertheless, their resistance to the female performers does confirm that they were aware of the effects of the male gaze. What they feared were the forbidden desires that would be aroused in them as they watched the sexually attractive women.

The image of the dangerous performing woman was handed down to later Christian critics of the theatre, especially in the seventeenth and eighteenth centuries. Evoking the writings of the Church fathers, these descendants also regarded the theatre in general as bad, sinful, and alluring, and female performers as the incarnation of that sin and temptation. Again, paradoxically, these men of the Church illustrate most convincingly the workings of the male gaze when writing fiercely against the female performers of their own time. ${ }^{84}$

As the phlyax vase paintings of Asteas show, the Greek acrobats and flute-girls were objects of the male gaze in a very literal way. From these early female performers a clear line is discernible through history until quite recent times. Women's artistic participation in theatre and performance was generally shaped and framed by men, according to men's preferences and desires. Sometimes their theatrical activities brought the women praise, applause, and fame, but the prize they paid for this was notoriety, along with the standard suspicions and accusations of prostitution. It is no coincidence that the first female performers appeared in the more or less illegitimate, low-status genres of Greek and Roman theatre, and that they themselves belonged to the slave population or were freedwomen.

The social stigma of female performers continued as a general condition after the entry of the first modern-age actresses in the sixteenth and seventeenth centuries, with the 
dancers, singers, and entertainers ranking as the lowest in the hierarchy. All through the centuries the female performers were not only 'victims' and 'objects', however, but also active 'subjects' as professional artistes. As such, the Greek and Roman tumblers, flute-girls, and mime actresses were important 'firsts' in the history of the performing arts. They have been rather 'hidden from history', but they certainly deserve 'a space of their own' in theatre and performance studies. $^{85}$

\section{Notes and References}

1. Sue-Ellen Case: Feminism and Theatre (Basingstoke: Palgrave Macmillan, 2008 [1988]); Elaine Aston, An Introduction to Feminism and Theatre (London: Routledge, 1995). "The "lost" female tradition' is the title of the last section in Aston's Chapter 2.

2. Aston, p. 24

3. Aston, in Case, 2008, p. xi.

4. Allardyce Nicoll, Masks, Mimes and Miracles: Studies in the Popular Theatre (London: Harrap, 1931), p. 36-7, 49-50, 84-5, 87, 92-9; Margarete Bieber, The History of the Greek and Roman Theater (Princeton: Princeton University Press, 1961), p. 50, 86, 106, 159, 165, 236-8, 249 . The 1961 edition is a revised and enlarged version of the original edition from 1939. Nicoll and Bieber were both indebted to Hermann Reich, Der Mimus (Berlin: Weidenmannsche Buchhandlung, 1903), the first important work on the subject, written from a literary rather than theatrical perspective. Rosamond Gilder, Enter the Actress: the First Women in the Theater (Boston: Houghton Mifflin Company, 1931) also includes some pages on the first female performers, but this work is without footnotes or similar references and bibliography.

5. Cf. Aston's headline, without the question mark, p. 15 .

6. Nicoll, however, prefers the term 'mimic actors' and 'mimic actresses', but mentions that 'the mimic actor ... was originally called a mimus, or a mime', p. 83 . On some occasions he uses mimus (plural mimi) for the masculine performers, and mima (plural mimae) for the feminine.

7. Cf. 'Definitions of the Mime', Nicoll, p. 8o-2. Nicoll even extended the term, to cover 'the popular theatre' all through the Middle Ages and - tentatively on to the Renaissance.

8. All through this section the books belonging to each group will be presented in chronological order (according to the most recent edition), with one exception: Case, 1988, and Aston, 1995, are treated as a 'pair'.

9. There is one small exception. Commenting on Euripides' comedy Thesmophoriazousae, Taplin mentions 'the male performers of the chorus, representing the women at the festival'. See John Russell Brown, ed., The Oxford Illustrated History of the Theatre (Oxford: Oxford University Press, 1995), p. 38. Otherwise, all performers are referred to as 'actors'.

10. Ibid., p. 63 .

11. The two illustrations appear on p. 63 and 64
12. Oscar G. Brockett and Franklin J. Hildy, History of the Theatre, 10th edition (Boston: Pearson, 2010, ), p. 55.

13. Ibid., p. 56.

14. Phillip B. Zarrilli, Theatre Histories: an Introduction (New York: Routledge, 2010), p. xxvii.

15. Ibid., p. 65.

16. Ibid., p. 102.

17. David Wiles and Christine Dymkowski, ed., The Cambridge Companion to Theatre History (Cambridge: Cambridge University Press, 2013), p. 75.

18. Ibid., p. 75 .

19. Bieber's book, 2nd edition 1961, appears in the bibliographies of the discussed works by Wiles, McDonald and Walton, and Beacham.

20. The illustrations occur on p. 50, 140, 144, 236, $237,249,251$. For the comments, see note 4 .

21. Nicoll's book was not included in the actual survey of 'textbooks', because it is a more specialized study. As already mentioned, however, Nicoll's discussion of 'mimetic actresses' is also quite comprehensive.

22. Richard C. Beacham, The Roman Theatre and its Audience (London: Routledge, 1991), p. 130.

23. Wiles, p. 13, 66-7, 76, 78 .

24. Marianne McDonald and J. Michael Walton, The Cambridge Companion to Greek and Roman Theatre (Cambridge: Cambridge University Press, 2007). In his essay Denard quotes a passage from Xenophon's Symposium (p. 151), to which we will return later, but does not point out that the 'Ariadne' of the performance described is actually a female performer.

25. McCart, p. 265, with an endnote referring to Ruth Webb, 'Female Entertainers' (see note 57).

26. J. Michael Walton, p. 292-3.

27. Cf. title of the first section of Case's Chap. 1, p. 5 .

28. Case, p. 29-31.

29. Aston repeats this opinion in her foreword to the new edition of Case's Feminism and Theatre (p. xi), referring to Case's text on 'women's "writing" for performance' by means of their 'bodies that danced, sang, or entertained through some kind, any kind, of popular rather than "high culture" tradition of textual privilege'.

30. Case obviously knew Bieber's book when she wrote her own volume, as it figures in the bibliography for Chapter 1 .

31. Aston, p. 15-16.

32. Ibid., p. 29.

33. Ibid.

34. Renate Möhrmann, ed., Die Schauspielerin. Zur Kulturgeschichte der weiblichen Bühnenkunst (Frankfurt am Main: Insel, 2000 [1989]), p. 10.

35. Lizbeth Goodman with Jane de Gay, The Routledge Reader in Gender and Performance (New York: Routledge, 1998), p. $25-8$.

36. Ibid., p. 25. It is not correct, however, that Isabella Andreini belonged to one of the 'unregulated, travelling troupes'. As is well known, she was a member of I Gelosi, which was a well-organized commedia dell'arte company.

37. A similar mixture of a general statement and a 'British bias' appears in the heading of Part Two, 'Women Taking the Stage: the History of Women in Theatre 1660-1960'.

38. Maggie B. Gale and John Stokes, ed., The Cambridge Companion to the Actress (Cambridge: Cambridge University Press, 2007), p. 1 .

39. See, for instance, Kenneth Richards and Laura Richards, The Commedia dell'Arte: a Documentary History (Oxford: Blackwell 1990), p. xv, 4. 
40. Gale and Stokes, p. 19.

41. See the 'Introduction: What Is Performance?', in Marvin Carlson, Performance: a Critical Introduction (New York: Routledge 2004), p. 2-3.

42. Bieber refers to this text three times (p. 50, 106 159), without quoting from it. Denard (p. 151) quotes from the last chapter, but does not mention the acrobatic performance that is described earlier in Xenophon's text.

43. Xenophon, Memoirs of Socrates and the Symposium, trans. with an introduction by Hugh Tredennick (Harmondsworth: Penguin, 1970), p. 235.

44. Ibid., p. 237, where the hoop dance and the sword dance are both described.

45. Ibid., p. 240.

46. Ibid., p. $266-7$.

47. Ibid., p. 278-9.

48. The translation quoted by Denard is somewhat more explicit at this point: 'Those already married mounted their horses and rode off to their wives, to enjoy them.'

49. Bieber, p. 50.

50. Bieber, p. 160. Nicoll (p. 35) shows a 'Greek acrobatic dancer' - apparently female - in a similar hoop position, depicted on a vase, unfortunately not dated.

51. C. W. Dearden, 'Pots, Tumblers, and Phlyax Vases', in Alan Griffiths, ed., Stage Directions: Essays in Ancient Drama in Honour of E. W. Handley (London: Institute of Classical Studies, University of London, 1995), p. 81-7, 83 .

52. Dearden, p. 86.

53. J. Michael Walton, Living Greek Theatre: a Handbook of Classical Performance and Modern Production (New York: Greenwood Press, 1987), p. 194, 206; and Kenneth McLeish, The Theatre of Aristophanes (London: Thames and Hudson, 1980), p. 153.

54. See for instance Ariana Traill, Women and the Comic Plot in Menander (Cambridge: Cambridge University Press, 2008); Elaine Fantham, 'Sex, Status, and Survival in Hellenistic Athens: a Study of Women in New Comedy', in Phoenix, XXIX, No. 1 (Spring 1995); and David Wiles, 'Marriage and Prostitution in Classical New Comedy', in Themes in Drama, XI: Women in Theatre (Cambridge: Cambridge University Press, 1989).

55. A number of the flute, harp, and dancing girls are mute roles, even if they are essential characters in the plot: for instance, Bacchis in Adelphoe and Pamphila in Eunuchus, both by Terence; Phrygia and Eleusium in Aulularia, and Phoenicium in Pseudolus, both by Plautus.

56. Evelyn Fertl, Von Musen, Miminnen and leichten Mädchen (Wien: Braumüller, 2005).

57. See also Webb's articles: 'Salome's Sisters: the Rhetorics and Realities of Dance in Late Antiquity', in Liz James, ed., Men, Women, and Eunuchs: Gender in Byzantium (London: Routledge, 1997), p. 119-48; and 'Female Entertainers in Late Antiquity', in Pat Easterling and Edith Hall, ed., Greek and Roman Actors (Cambridge: Cambridge University Press, 2002), p. 282-303. Demons and Dancers was published in Cambridge by Harvard University Press, 2008.

58. 'Female Entertainers', p. 284-5. I refer to the terms in the singular. See also Fertl's distinction between various specialities in the two categories 'actresses' and 'dancers', p. v.
59. According to Nicoll, many of the mime performers 'seem to have come from Greece, and still more from Syria and the Farther East', p. 94.

6o. The Greek original and English translations are rendered in several books. See for instance W. Beare, The Roman Stage: a Short History of Latin Drama in the Time of the Republic (London: Methuen, 1968), p. 369.

61. Simon Trussler, The Cambridge Illustrated History of British Theatre (Cambridge: Cambridge University Press, 1994), p. 2.

62. Ibid.

63. Webb, 'Female Entertainers', p. 286-7; Beacham, p. 152,194

64. Webb, 'Female Entertainers', p. 291; Webb, Demons and Dancers, p. 46. See also Fertl's chapter on 'Mimenvereine und collegia', p. 57-66.

65. Webb, 'Salome's Sisters', p. 129; and Webb, 'Female Entertainers', p. 291.

66. See the alphabetical list presenting all the names in Fertl's 'Appendix I: Prosopographie römischer Schauspielerinnen', p. 169-99. This is the most comprehensive and systematic overview of evidence concerning each of them.

67. Nicoll, p. 87, 96-7, Webb, 'Female Entertainers', p. 289; Webb, Demons and Dancers, p. 22, and Fertl's alphabetical list. Trussler suggests that the unknown Verecunda might have been an archimima, op. cit., p. 4

68. Webb, Demons and Dancers, p. 22.

69. Webb, 'Female Entertainers', p. 283.

70. Webb, Demons and Dancers, p. 210-14. See also Walter Puchner, 'Acting in Byzantine Theatre', in Easterling and Hall, Greek and Roman Actors, p. 307, 313.

71. Webb, 'Female Entertainers', p. 282-3, 298; Webb, Demons and Dancers, p. 4-6, 142; Nicoll, p. 98

72. See Bieber, p. 237.

73. Nicoll, p. 92.

74. Webb, Demons and Dancers, p. 48, 156

75. Ibid., p. 101. See also Fertl's extensive discussion: 'Die Entblössung der Miminnen (nudatio mimarum)', $\mathrm{p}$. 15-22.

76. Webb, 'Female Entertainers', p. 288.

77. Webb, Demons and Dancers, p. 49. The following section on prostitution and social stigma is mainly based on Webb's work, op. cit., p. 49-57. See also Fertl's chapters on 'Die Soziale Stellung', p. 80-100, and 'Prostitution und Schauspiel', p. 152-67.

78. On the infamia, see also Jonas Barish, The Antitheatrical Prejudice (Berkeley: University of California Press, 1981) p. 42-3.

79. Case, p. 30.

80. Laura Mulvey, 'Visual Pleasure and Narrative Cinema', in Leo Braudy and Marshall Cohen, ed., Film Theory and Criticism: Introductory Readings (New York: Oxford University Press, 1989 [1975]), p. 19.

81. Case, p. $118 \mathrm{ff}$

82. Webb, 'Salome's Sisters', p. 134.

83. Ibid. For an in-depth discussion of this issue, see B. Leyerle, 'John Chrysostom on the Gaze', in Journal of Early Christian Studies, I, No. 2 (1993), p. 159-74.

84. For interesting examples of these antitheatrical writings, see Ferdinando Taviani, ed., La Commedia dell'Arte e la Societá Barocca: la fascinazione del teatro (Roma: Bulzoni, 1970).

85. Cf. Aston in Case, 2008, p. xi. 